\title{
LITERATURE
}

DOI https://doi.org/10.30525/978-9934-26-073-5-1-21

\section{О НЕКОТОРЫХ ОСОБЕННОСТЯХ ХУДОЖЕСТВЕННОГО ПРОСТРАНСТВА И ВРЕМЕНИ В РОМАНЕ А. МЁРДОК «ВРЕМЯ АНГЕЛОВ»}

\author{
Алисеенко О. Н. \\ кандидат филологических наук, \\ дочент кафедры английского языка \\ для нефилологических специальностей \\ Днепровского национального университета имени Олеся Гончара \\ г. Днепр, Украина
}

Особенности художественного пространства и времени, предшествующего «Приятному и Благому» «готического» романа А. Мёрдок «Время ангелов'» («The Time of the Angels»,1966), в котором 'бушуют демонические страсти и образы насыщены темной символикой» $[1$, c. 111] и разгадкой которого служат аллюзии на философские идеи Ницше и Хайдеггера [2, с. 80], прямо ему антиномичны. Это «закрытое», изолированное, холодное, мрачное пространство одиночного лондонского дома демонического священника-отступника Карела Фишера, поправшего этические нормы «двойного отца» («doubly-fathered father»), по мнению Д. Джонсон [3, с. 66], т.е. отца семьи и священника. Ситуация отгороженности от мира в одиноком закрытом доме, атмосфера темноты, затхлости, разрушения, холода, мрака, отчуждения (Карел боится света, надевает черные очки, исполняет ритуальный танец под музыку), мотив инцеста, черно-белое пространство перекликаются с готическим модусом в трактовке топоса, служат выразительной характеристикой центральной, таинственной, «закрытой» фигуры романа «Время ангелов». П.Конради видит в нем «апокалиптический», готический и религиозный роман, отмечает черты «черной комедии», называя его 'клаустрофобическим ромэнсом' [4, с. 132-137], а И.Левидова определяет «Время ангелов» как психологический «роман-портрет» извращенной личности [5, с. 441]. Думается, что в этом романе просматривается идея перевернутого мира, релятивности ценностей, не абсолютности Добра и Зла, основанных на полемике с экзистенциализмом, которому писательница имплицитно противопоставляет платоновские концепции 88 
единства Любви, Красоты, Блага, Добра, прямо художественно реализовавшихся в «Приятном и Благом». Думается, что во «Времени ангелов» идея ценностной дезориентации современного человека, соотнесенная с крахом христианской морали, сопряжена также с экзистенциальной проблематикой потери смысла, свободы выбора, восходящей к богоборческой традиции романтической философской антропологии, Ницше, Сартру, Камю.

Уже само заглавие романа актуализирует тему времени и соотносится романисткой с действием времени «мира без Бога», а один из героев романа называет эпоху смерти Бога «междуцарствием». Персонажи романа мучительно размышляют о том, какая вера последует за крушением христианских ценностей. Дает толкование заглавию «Тhе Time of the Angels» и один из центральных героев романа - священникеретик Карел Фишер: «Смерть Бога выпускает на свободу ангелов. И они ужасны... Бог, по крайней мере, был именем того, что мы считали добром. Теперь даже имя его утрачено, а духовный мир потерпел крах» [6, с. 189]. Название романа Мёрдок как бы перекликается с «Бесами» Достоевского, произведением в котором также звучит тема утраты ценностей и нигилизма, и с сатирическим романом А.Франса «Восстание ангелов» (1914), в котором преломляется отношение писателя к русской революции 1905 года.

Сложный идейно-тематический комплекс романа, Мёрдок воплощает через художественное воссоздание проблем индивидуального сознания современного человека, что является константной чертой философскопсихологической прозы писательницы. И роль художественного пространства и времени в этом произведении представляется чрезвычайно важной для всех его уровней: концептуальном, фабульном, образном, структурном.

А.Мёрдок обогащает полисемантику образа Карела Фишера пространственной экзистенциальной символикой: это и вертикальная организация пространства (Карел, взявший на себя роль бога, живет в верхнем ярусе дома); это полуразрушенная церковь, как метафора его разрушенной веры, холод, густой туман, отмечается и постоянная темнота, метафоризирующая состояние его духа; это распавшаяся семья как символ деструкции, заключенный в утратившем Бога отцесвященнике; это и не проходящее состояние страха, боязнь случайного и непредвиденного, заставляющее героя жить в закрытом топосе дома, и, наконец, самоубийство героя как закономерный итог его экзистенции.

В контексте демифологизации христианства, дом священника предстает чем-то наподобие клаустрофобического явления. Мотив 
замкнутого пространства, некоего предела, несвободы постоянно акцентируется А.Мёрдок. Внутри закрытого дома находится комната Элизабет, носящей стальной корсет, угольный погреб, в который падает Маркус, платяной шкаф, где прячутся Мюриэль и Лео, русская шкатулка с Русланом и Людмилой, сокрывающая «демона памяти» - традиционный набор предметных символов для писательницы, универсально трансформирующийся и эксплуатирующийся в романах поздней Мёрдок (например, «Море, Море», 1978).

Время в романе «Время ангелов», соотнесенное с войнами и русской революцией, можно назвать эпохальным: это время утраты идеалов, поиска смысла жизни, период глобальных катастроф, после которых приходит пора обретения новой веры, установления новых ценностных ориентиров.

Образ Юджина Пешкова, который вводит в произведение русскую тему, многослойно пронизывающую всю художественную ткань «Времени ангелов» и многократно обыгрывается автором в системе мифологем, аллюзий, предметных символов, (как и Карела Фишера), притягивает круг полисемантических предметных символов. Наиболее значимым из них является семейная реликвия Юджина, русская православная икона, изображающая Святую Троицу, обладающей особой концептуальной и сюжетной функцией в романе. В ее судьбе принимают участие практически все герои романа: Лео ворует ее, Маркус выкупает и приносит в дом Карела, Мюриэль хочет лично отдать ее владельцу, завоевав тем самым его любовь, однако только Пэтти оказывается той, которая приносит Юджину икону и счастье. Это произведение искусства, вызывающее добрые и светлые воспоминания о прошлом, о котором напоминает ему и расписная шкатулка с Русланом и Людмилой, вероятно, в какой-то мере имплицирует не проходящую веру Юджина Пешкова в Благо-Добро.

В «Приятном и Благом» аллегорическая картина художникаманьериста Бронзино тоже занимает особое место, являясь одним из концептуальных ключей романа, но семантическое пространство картины подробно воспринимается и интерпретируется лишь одной из героинь и, хотя влияет на жизненно важное решение героини, на фабульное развитие, однако столь тесно не увязано с ним, как икона во «Времени ангелов», оказавшаяся, как и картина Тинторетто в «Дикой розе» предметом продажи. В «Приятном и Благом» картина известного художника-маньериста Возрождения находится в музее, не являясь частной собственностью, обретает знак вечно прекрасного бесценного произведения искусства, благотворно влияющего на людей. 
Неоплатонический пафос идейного компонента «Приятного и Благого» формирует такую интерпретацию эмфазы.

Роман «Время ангелов» уже привлекал внимание специалистов, однако продолжает оставлять место для истолкований. Вероятно, в романе просматривается идея перевернутого мира, релятивности ценностей, не абсолютности Добра и Зла (открытая концовка романа, смерть Карела, ведет к преображению, к продуцированию Добра). Именно это приводит писательницу к полемике с экзистенциализмом, которому она противопоставляет платоновскую концепцию единства Красоты и Добра.

\title{
Литература:
}

1. Ливергант А. Вариации на тему: «О последних романах А.Мердок». Литературное обозрение, 1986. №1.

2. Martz I. Iris Murdoch: The London Novels. Twentieth Century Literature in Retrospect. L.,1971.

3. Johnson D. Iris Murdoch. L., 1987.

4. Conradi P. I. Murdoch: The Saint and The Artist. L., 1986.

5. Левидова И. Послесловие. Мердок А. Дитя слова. М., 1981.

6. Мердок А. Время ангелов. С.П., 1995.

DOI https://doi.org/10.30525/978-9934-26-073-5-1-22

\section{ЦІННІСНІ АСПЕКТИ МОДЕЛЮВАННЯ ФІКЦІЙНОЇ СВІДОМОСТІ ПЕРСОНАЖА В ДРАМІ Ю. ЯНОВСЬКОГО «ДОЧКА ПРОКУРОРА»}

\author{
Атаманчук В. П. \\ доктор філологічних наук, дочент, \\ провідний науковий співробітник \\ відділу організачії наукових досліджень \\ Національного педагогічного університету імені М. П. Драгоманова \\ м. Київ, Украӥна \\ У драмі Ю. Яновського «Дочка прокурора» (1953) значна увага \\ приділяється визначенню моральних параметрів дійових осіб з огляду на \\ відтворену у п'єсі драматичну ситуацію та окресленню ціннісних \\ трендів у суспільстві. Тому дослідження процесу моделювання фікційної
}

